\title{
The mystery of the missing core in Pauline theology: The case for a multi-dimensional interpretation with reference to J H Roberts and J C Beker
}

\author{
J A Loubser \\ University of Zululand
}

\begin{abstract}
This article analyses features concerning the search for a centre for Pauline theology and indicates why such an endeavour is better carried out within the context of multi-dimensional scriptural exegesis. The text theory used for this purpose is that of $A J$ Greimas as developed by $D$ Patte and originally elaborated by the author of this article ( $J$ A Loubser).
\end{abstract}

\section{INTRODUCTION}

In New Testament studies the search for a centre of Pauline theology may be comparable to the quest for the historical Jesus in Synoptic studies. It has not only been described as the most burning question of Pauline studies," but has also seen much activity during the past decades. The notion of a "centre" goes back to the concept of centrum scripturae first mentioned by Johann Gerhard in 1637 and derives from Luther's description that Christ is the centre of a circle and that all histories in Holy Scripture refer to him. ${ }^{2}$ The search for the "Mitte" of Pauline theology has become popular since the 1960's in

\footnotetext{
${ }^{1}$ Boers (1988)

2 “... das Christus sej der Punct im Circkel ... . Den er is das mittel. Punctlein im Circkel, und alle Historien in der heiligen Schrieft ... gehen auff Christum" (WA 47, 66, 21-24).
} 
Germany and is still pursued in various forms. ${ }^{3}$ The question has shown a remarkable resilience while undergoing new adaptations with the later introduction of structuralist, literary, narrative and rhetorical analyses in New Testament studies.

One of the great advances in this field was made by J C Beker, who provided the impetus for a ten-year discussion at the Pauline Theology Group at the SBL. By the time of the completion of a program to describe the theology in the main letters in 1995 the participants were apparently further away from a solution than ever before, though the debate was characterised by an increasing theoretical sophistication. Nevertheless, contributions still exhibited much interest in a coherent centre in Pauline theology. The most recent comprehensive theology of Paul, in which the discussion of the search for a centre features, is that by James D G Dunn (1998). ${ }^{4}$

The fact that the issue remains unresolved raises some serious questions. Could it be that the (explicit or implicit) search for a "core" is a left-over from a modernistic hermeneutic trying .. to organise the material into a "grand narrative", motivated by the desire to manipulate the text as part of a (Western) power game? Or, can one ask, is the search for a core perhaps founded on a misunderstanding of the mode of theologising in the first century, and indeed of manuscript production itself, overlooking the oral poetics of Paul the apostle and his audiences? For an answer to these questions we turn to a brief overview of the search.

\section{IN SEARCH OF A CORE}

\subsection{The initial stages of the search}

At present the data on the search for a Pauline centre is extensive. What began as an enterprise to understand the breaks in the Pauline texts, differing representations of the

\footnotetext{
3 "Wir verkündigen Christus als den Gekreuzigten (1 Kor 1, 23 - die Kreuzesbotschaft des Apostels Paulus als Mitte seines Evangeliurns" (Orikemper 1968:5-12).

4 Dunn's contribution is not discussed in this article as I have treated it in a forthcoming article. "Will Pauline theology survive post-modem hermeneuties?" (Loubser, NGTT 2000).
} 
same issues ${ }^{5}$ and even contradictions ${ }^{6}$ developed into a major examination of Pauline hermeneuties and theology. Much of the Pauline peculiarities can be explained with reference to contextual factors, but there also are much that do not have a direct bearing on the immediate context - for example, lists of greetings, house tables, lists of virtues and vices. The elusiveness of the opponents also implicated in the letters adds to the problem.

That, which is agreed upon by scholars, is that the concepts in the Pauline letters cannot simply be harmonised without neglecting some major aspect. The time when one theme could be proposed as the (reasonably controllable, fixed) "centre" of Pauline thought, has long since passed. This was an experiment that began with Marcion, who understood faith to be central. His radicalism was rejected, but the same methodological presupposition is found with Augustine, Luther and Calvin and runs through to Bultmann, Barth and Käsemann. Within this paradigm it was accepted that the theological centre was self-explanatory and could be described in terms of generally accepted principles.

Such a model can be graphically represented as a fixed centre (the circle) with fairly simple connections to the text (the rectangle).

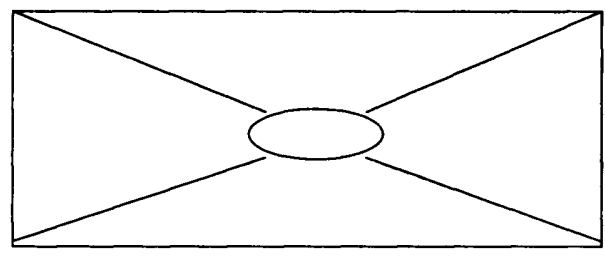

\footnotetext{
${ }^{5} \mathrm{E} g$ the differing christologies in $\mathrm{Rm} 1$ and Phlp 2.

6 "It is the easiest thing in the world to find verbal contradictions in Paul, and this means neither that he was unprincipled nor that he kept changing his mind" (Lowe 1941:140). Cf Statements on the parousia: in 1 Thessalonians Paul is of the opinion that he will personally experience the parousia, while in Philippians 1:21 he reckons that he will die before the parousia. In 1 Corinthians 14 it seems as if there is to be a period between the death of a believer and the parousia, while in Philippians 1:23 it is said that the deceased will immediately be with Christ. Cf also the way in which a person will exist after death. Lowe is of the opinion that 1 Corinthians proposes a sudden change from a humble to a glorified state; in 2 Corinthians 4 the change is seen as a gradual one. In 2 Corinthians 5 it is said that the spiritual bodies with which believers will be clothed are eternal, as if they are waiting on heavenly shelves! (Lowe 1941:136).
} 
This model, however, presented two insurmountable problems:

- In the research history no unanimity could be reached on a uniform model for the centre.

- No single proposed centre could adequately relate the particularity of the various letters with the centre.

The question therefore remained as to how the universality and the catholicity of the letters could be maintained if the author(s) composed specific letters to specific churches. ${ }^{7}$ Gradually the conviction took hold that if a centre were to be found, it would be more dynamic and would have to be sought at a deeper level in the text.

Already in the previous century a new approach was explored. Since Weiss in 1891 emphasised the importance of eschatology for the New Testament for the first time, and Albert Schweitzer developed his model of a "consistent" eschatology and eventually his "two crater theory", the idea of a shifting centre gained plausibility. C H Dodd, a more recent exponent of this model distinguished between futurist eschatology and a realised phase (Christ mysticism). This represented a shift in Pauline thinking away from an apocalyptic dualism with its negation of the present order to a new appreciation of human institutions. ${ }^{8}$ The great shift was perceived to be evidenced in 2 Corinthians 12:110 , though it is now accepted that apocalyptic traits also appear in the later letters and are not in conflict with the house tables. ${ }^{9}$

\footnotetext{
${ }^{7}$ Cf Beker (1988:364) following Dahl (1962).

${ }^{8}$ The former is evident from 1 \& 2 Thess and 1 Cor, the latter in 2 Cor and further - of which the positive evaluation of the authorities (Rom 13) and the house tables in Colossians are typical.

9 CfC H Dodd (1953).
} 
In the diagram below, the perforated lines represent the second centre:

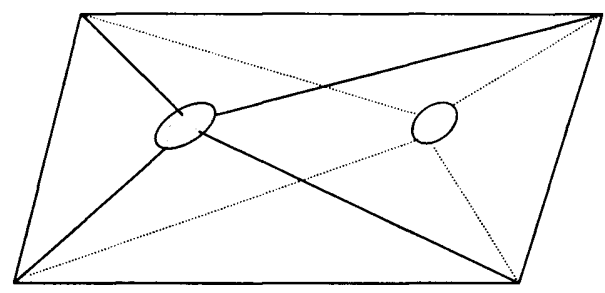

As a comprehensive discussion of developmental theories is not possible in this article, we can only note some points of criticism:

- No agreement could be reached on the nature of the development;

- The uncertain chronology of the Pauline texts leads to circular arguments;

- A theory of major shifts in Pauline thinking clashes with the apostle's own perception. He only reports one such shift, that is his Damascus experience;

- No developmental model could thus far explain the coherence of the Pauline materials.

\subsection{More recent research}

Since the 1960's a series of Pauline scholars have forwarded a variety of approaches. In his authoritative study H Ridderbos (1971:40-93) avoided the concept "centre" but his description of the "fundamental structures" of the Pauline theology amounts to more or less the same idea. At the basis of these fundamental structures we find a formal principle which he describes as eschatological salvation history - Christ's cross and resurrection that functions in a dialectical relationship with the Parousia. Longenecker (1985:87) takes the Christology as point of departure (centre) for Pauline theology. "Rather than christology being derived from eschatology the Thessalonian letters indicate that eschatological hope was based on a functional christology" (Longenecker 1985:89). 
In 1977, E P Sanders formulated the commanding vision of Pauline thought as: "The is nigh, Christ is the Lord and only those who belong to the Lord shall be saved on the day of the Lord." In 1983, he expressed a more nuanced view saying that one must distinguish between the reason why Paul had a conviction and the arguments he advanced: "Paul held a limited number of basic convictions, which - when applied to different problems, led him to say different things about the law" (Sanders 1983:147).

Sanders thus affirmed the view that Paul was a coherent thinker in spite of his haphazard expressions and changing formulations. ${ }^{10}$ He viewed this theological coherence as "participation in Christ rather than justification in faith" (Plevnik 1989:471). According to him one can detect this coherence by examining the text in the light of four questions:

- What is the underlying conviction that explains this theology?

- How does one get in?

- How does one stay in?

- What is the goal of the religion?

Another theorist, Moule (1959:247ff), concludes: “... I tried to show that christological formulations were dominated first by one emphasis, then by another, not always according to chronological sequence but rather according to their particular purposes, whether it was worship and adoration, explanation and defence, or, perhaps, even attack." He describes the particular situations in terms of "convictions that need to be safeguarded." The variations are not due to a delayed parousia, nor changing moods, but because of an intellectual dilemma; "... formulations are to be found which may be both mutually incompatible, and, equally, incapable of being plausibly arranged as successive stages in an evolutionary order of development; and that they are best explained as the result, simply, of the unmanageable dimensions of Christian verities." He explains:

${ }^{10} \mathrm{Cf}$. Sanders as quoted in Plevnik (1989:466). 
... All that Paul can do is to nail down or "peg" first one insight and then another, as need arises, without attempting a coherent, architectonic scheme or logical series .... The "pegs" were driven in ... not in as developing sequence all round, but on opposite and complementary sides, preferably simultaneously, or at least alternately. In handling the greatest and most paradoxical convictions of the Christian faith, something like this is bound to happen .....

(Moule 1964:4)

Ad hoc statements are, as Papias expressed, "pros tas chreias", according to the need of the situation and not because of logical necessity (cf Moule 1964:11 ff).

\subsection{Roman Catholic views}

In general, Roman Catholic scholarship emphasises the continuity between Pauline theology and the rest of the New Testament. For L Cerfaux (in Plevnik 1989:462) the centre is "Christ, the Son of God". R Schnackenburg (1989:463) says, "Jesus' death and resurrection is the origin of Paul's Christology. It is from this twofold event that the apostle draws out all the conclusions regarding the meaning of Jesus Christ". ${ }^{11} \mathrm{~J}$ Fitzmeyer (1967) is of the opinion that "the centre of the apostle's theology is Christ or christocentric soteriology."

Plevnik (1989:468-469) finds regarding Paul: "His formulations are not repetitive, but always fresh and tailored to the particular circumstance. Pauline letters reveal an amazing constancy of belief, message, and apostolic activity. We shall concentrate our search for the centre on the primal reality from which he draws his entire theology." According to Plevnik (1989:476-478) the centre is the death and resurrection of Christ and its fundamental meaning of salvation and participation. Any centre of Pauline theology would include the following elements (Plevnik 1989:477-478):

- $\quad$ His understanding of Christ and of God;

- $\quad$ His understanding of God's salvific action through Christ;

$"$ Vide Mysterium Salutis 3(1), 227-338 esp 323). 
- The Easter event and its implications;

- The present lordship;

- The future coming of Christ; and

- The appropriation of salvation.

"The centre is thus not any single aspect of Christ, or of God's action through Christ, but rather the whole and undivided richness and mystery of Christ and of the Father's saying purpose through his Son. Although Paul derived his theology now from one aspect of Christ, now from another, he preached the whole Christ" (Plevnik 1989:478).

\subsection{J C Beker}

As the scholar who provided the greatest impetus for research in Pauline theology the past decades we now turn to $\mathrm{J} \mathrm{C}$ Beker. He suggested a model that would mediate between a pure sociological or rhetorical analysis on the one hand and a rigid dogmatic approach on the other hand $(1986: 602 ; 1988: 368)$. His model depends on two observations: (a) that there are no fundamental shifts in Pauline thought; and (b) there are irregularities that cannot be systematised. In response to these observations he suggests a model in which a distinction is made between the coherence and the contingency of Pauline theology. The relationship between these two poles is described as the interface. These terms represent his substantial contribution to the debate, defining the coherence (centre) in terms of the concept of a deep structure. The apparatus for this description is borrowed from the transformational generative grammar, although he never explicitly refers to it (as far as this author could gather). He describes the coherence as follows:

By "coherence" I mean the stable constant element which expresses the convictional base of Paul's proclamation of the gospel: he (Paul) refers to it as the "truth of the gospel" (Gal 2:5, 14), apostasy from which constitutes an apocalyptic curse (Gal 1:8,9)... By contingency I mean the variable element, i. e. the variety and particularity of sociological, economic and psychological situations which Paul faces in his churches on the mission field. Thus the interaction between coherence and contingency focuses on the question how 
the abiding Word of the gospel becomes a word on target, i. e. fulfil its function as gospel.

(Beker1986:596)

In Paul, the Apostle Beker described the coherent centre as something consisting of "a symbolic structure in which primordial experience (Paul's call) is brought into language in a particular way. The symbolic structure comprises the language in which Paul expresses the Christ-event. That language is, for Paul, the apocalyptic language of Judaism, in which he lived and thought. The symbolic structure then is the result of the translation of Paul's primordial experience into his basal language and constitutes for him the necessary interpretation of the Christ-event" (Beker 1980:14-1 5).

Further, Beker (1980:16) maintained, “... the symbolic structure signifies the contingent interpretation of Paul's Christian apocalyptic into a particular situation." The apocalyptic component therefore belonged to both the deep and the surface structure and supplied the "horizon of understanding, interpretation and application, hence a cohesive framework" (Plevnik's words, 1989:473).

According to him the coherence cannot be expressed by a single formula. Nevertheless he describes it as "apocalyptic." The proclamation "conforms to its apocalyptic shape" and is preached "in such a way that it inserted itself into the concrete and various particularities of people's lives."' 12 Beker further maintains that "Paul's apocalyptic gospel is constituted by certain apocalyptic components that he derives from his Jewish apocalyptic world and that he radically modifies because of his encounter with Christ and the Christian tradition he inherits" (Beker 1982:30).

\subsubsection{Apocalyptic components}

The four basic elements of Jewish apocalyptic are the themes "vindication", "universalism", "dualism" and "imminence". These themes. "however modified by the event of Christ, form the coherent centre of Paul's gospel" (Beker 1982:14-15). For the sake of

\footnotetext{
${ }^{12}$ Cf Beker (1982:29ff)
} 
clarity it is necessary to briefly note what Beker understands under these four "themes" (Beker 1982:55):

1) Vindication. In the death and resurrection of Christ, the God of Israel has confirmed and renewed his promises of salvation to Israel and the nations. The idea that God will be vindicated is expressed by a salvation-historical motif.

2) Universalism. This motif differs from the Jewish thinking which remains introverted (Beker 1982:360). Beker refers to Käsemann's statement that anthropology is cosmology in concreto - "for Paul the human being is involved in the world-wide conflict between the kingdom of God and the kingdom of this world" (Beker 1982:36). On the other hand he sees a profound interdependence between the people of this world as well as an absence of dualism between the human soul and the external world. Beker further observes that "the apocalyptic motifs of vindication and universalism are shown to be interrelated ..." (Beker 1982:38).

3) Dualism. In Jewish apocalyptic there is an antithesis between this world and the world to come. Paul tempers and intensifies this dualism. "God's plan for the world engages the Christian in a battle against the present structures of the world" (Beker 1982:44). This motif involves a theology of matyrdom.

4) The motif of imminence intensifies the other motifs and "thus heightens the hope for the actualization of God's vindication and universal reign ..." (Beker 1982:44). He describes this aspect as the futurist-imminent. The theme of imminence has three aspects - its necessity, its incalculability and the dialectic of patience and impatience. The imminence motif in Paul's letters then, is even more intense than in Jewish apocalyptic. The death and resurtection of Jesus Christ intensify it, because that event marks the incursion of the future into the present (Beker 1982:47). Paul lives in the time of the end (Beker 1982:49). No philosophy of history or predictive eschatology is possible.

Eschatology and missionary strategy do not contradict one another.

\subsubsection{The interface}

Between coherence and contingency there exists a fluid mutual relationship. "I call this correlation of thought and practice the reciprocal relationship of coherence and 
contingency" (Beker 1982:55). This method corresponds according to Beker with the method of Third World theologians (Beker 1982:55). It prevents a "static, fixed-unalterable structure of thought" and can also be described as "a circular movement between coherence and contingency which aptly describes the 'contextual' nature of the coherent 'text' in Paul" (Beker 1986:599). There is thus a dialectical movement between the truth of the gospel and its relevance for people in their concrete lives (Beker 1986:602). In the process the apostle runs the risk of compromise (Beker 1986:599).

About how to find a "word on target" for a specific situation, he explains: “... the locus of the interaction between coherence and contingency is the Holy Spirit and because the body of Christ is in turn the locus of the Spirit, the body of Christ constitutes the place where the hermeneutical activity takes place" (Beker 1986:600). The church is described as a pneumatic democracy. It is the Holy Spirit who maintains the proper bond/synapse between the coherence/contingency and evaluated the appropriateness of the hermeneutical interpretation (cf 1 Cor 12:10; Rom 12:2 dokimazein - Beker 1988:369-370). The inter-relationship between nous and pneuma (1 Cor 14 and 2 Cor 4) characterises the hermeneutic strategy of coherence/contingency by members of the church. The hermeneutic framework of coherence and contingency is thus no abstract individualistic activity of the apostle and neither an action taught by rabbi's but a pragmatic consensus-forming action in the body of Christ where relevant and true evangelical strategies are designed for specific problems.

Beker (1988:370) uses a metaphor to illustrate the interface:

The interface resembles a military command center that dispatches the necessary material according to the needs of the various field units. The symbol of "righteousness", for example, is proper for the situation in Galatia and Rome, but it does not meet the needs in Corinth, where other symbols like "wisdom" and "knowledge" are employed. In this manner the contingency of the situation compels an interpretation of the coherence of the gospel, which must guarantee both its authenticity and its relevance. 
This model can graphically be represented as follows:

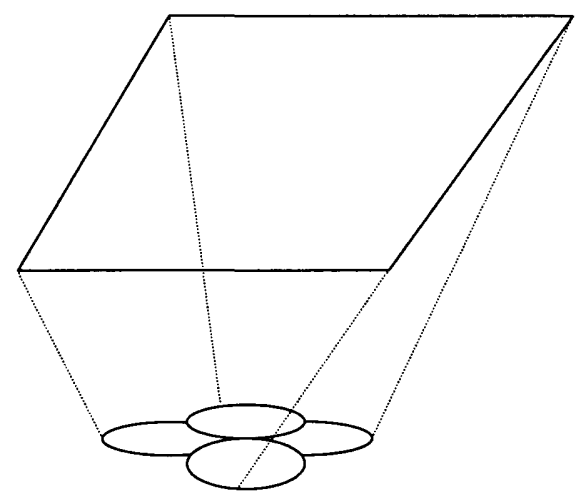

In the above diagram the four intersecting circles represent the formal elements ("themes") of the apocalyptic structure. The perforated lines indicate the interface, while the parallelogram represents the text.

\subsubsection{Inconsistencies in Beker's model}

After the first publication of his major book, Paul, the apostle (Beker 1980), several points of criticism were raised that encouraged Beker to explain his model in finer detail. The most important point of criticism was his description of the coherence as "apocalyptic". H Boers' criticism was that a centre could not be found in a particular idea. "The centre of Paul's thought transcends every instance of its expression" (expressed in a paper in 1986, published 1988). But this is exactly what Beker tried to avoid. He reacted: "I suggest that Jewish apocalyptic is the substratum and master symbolism of Paul's thought because (1) it constituted the linguistic world of Paul, the Pharisee and therefore (2) forms the indispensable filter, context and grammar by which he appropriated and interpreted the Christ-event ..." (Beker 1986:598). By this he did not mean that Paul had definitive apocalypses as literary "Vorlage" - "I mean that apocalyptic motifs dominate Paul's thought; that Paul's modifications of the Christian 
tradition are basically not due to Hellenistic-Jewish or Philonic influences but are modifications of an apocalyptic substratum" (Beker 1986:598ff).

Beker conceded that his mentioning of apocalyptic "themes" were misleading and he also concedes that "coherence cannot be restricted to on 'contingent' symbol, for instance the eschatological triumph of God, because it (viz. the coherence) implies a network of symbolic relations and does not refer to one specific idea or Mitte. The coherence of the gospel is constituted by the apocalyptic interpretation of the death and resurrection of Christ" (Beker 1986:598). By apocalyptic he understands "the imminent apocalyptic triumph of God." However, in his popular treatise, The coming triumph of God (Beker 1982), he explains the apocalyptic substratum as having a cognitive base. The same applies to his analysis of Romans in 1988. It is a remarkable inconsistency that he on the one hand describes the coherence as a formal structure, but on the other hand cannot help but to give it concrete meaning.

To clarify the uncertainty regarding what he understands under coherence, he explains that he deliberately moved away from the term "core" because of Bultmann's distinction between "core" and "husk" (separating a central conviction from its linguistic expression). It also is a reminder of the search for a Mitte that controls all other expressions in the tent. The concept Mitte reminds of a "fixed-nonpliable substance." "The term 'coherence' suggests a fluid and flexible structure. In contrast to a fixed core and a specific centre or particular symbol, it points to a field of meaning - a network of symbolic relations which nourishes Paul's thought and constitutes his 'linguistic world"' (Beker 1986:597).

Later Beker (1988:369) expressed the same idea in still a different manner: "My understanding of coherence as a symbolic universe, which is inseparably related to its contingent expressions, does not permit the equation of Paul's symbolic universe with a particular centre, core, Mitte, or with a particular metaphor. This means that the apocalyptic symbolic universe of Paul cannot be defined in a neat conceptual way and cannot be equated with one particular metaphor such as justification, reconciliation and so forth. It resembles in some respects the coherent field of interlocking and intersecting circles on the Olympic flag, which although distinct in their location and function are nevertheless 
held together by a unifying bond, that is in Paul's case the apocalyptic substratum of his thought" (Beker 1988:369).

\subsubsection{Conclusion}

In conclusion, Beker also proves to be inconsistent in his use of metaphors to explain his method. He sets out to explain coherence by means of a series of new hermeneutical concepts. Initially he calls it a deep structure ("which expresses the convictional base of the apostle's proclamation"). Subsequent descriptions include such concepts as a field of meaning, an apocalyptic substratum and master symbolism, apocalyptic symbolic universe, as something that constitutes the linguistic world of the apostle, as an indispensable filter, context and grammar, and as a network of symbolic relations.

Beker asks himself the question whether the coherence/contingency-scheme is a sufficient method for the study of the Pauline corpus as a whole (he knows it is adequate for a single letter). In this regard he remarks that the fluidity of the interaction between the coherence/contingency and its circular movement makes "a proper delineation of the boundaries of the coherent and the contingent very difficult - if not impossible. Can it not be said that one person's contingency is the other's coherence?" (Beker 1988:370).

\subsection{Other approaches}

We briefly note some of the other approaches that have been explored. Seyoon Kim (1981) saw the origin of Paul's gospel as a vision of the glory of God. Richard Hays at a narrative substructure of Pauline theology, Hans Hübner $(1990,1993)$ studied Pauline theology on a par with all theology in the New Testament as a conscious reflection on the Old Testament, N T Wright (1991) did not attempt a comprehensive theology of Paul, but his work on the Paul and the Law, suggests that the main thrust of his theology was a groundbreaking new insight in the relationship between the Law and grace. A last view we examine in more detail is that of a South African scholar, J H Roberts expressed at his inaugural lecture at the University of South Africa in 1974 (published in Afrikaans 1975). Because it is a thoroughly motivated view, in discussion with the best scholarship at the 
time and a view still reflected in the influential South African textbook series, Guide to the New Testament, ${ }^{13}$ it seems to be a profitable enterprise.

According to Roberts a centre has to be consistently and factually applicable and therefore has to be different from a theme that is used to address an ad hoc situation. The centre should rather be a "theological centre out of which Paul thinks, deals with problems and provides the answers" (Roberts 1975:15). He warns against a too narrow (e $\mathrm{g}$, in terms of a theme) or too wide a formulation of the centre (e g, Ridderbos who uses the "principle" of "eschatological salvation history" as a formal principle and not a material principle - though one fails to grasp the difference between a theme and a material principle). He also does not intend to discover the theological centre of the historical person Paul, but rather of the corpus Paulinum.

For Roberts Pauline theology has Christ at its centre. But Christ only makes sense as centre when Pauline eschatology is seen from perspective of salvation history (Roberts 1975:12). Elsewhere he notes that, "the cross and resurrection of Christ is the centre of salvation history" (Roberts 1975:13). Under salvation history he understands that God's actions follow a historical pattern, that is that of the covenant of grace, the law acting as custodian, punishment for transgression; by his cross and resurrection Jesus inaugurates the eschatological time, the time leading to ultimate fulfilment; in the present time the Holy Spirit anticipates salvation.

As a further step in his argument Roberts (1975:13) states that for Paul God is the centre. Throughout the letters there is the basic realisation that God's time of salvation has arrived. "Paul's statements about the dawn of and hope for the end time can only be understood in terms of the Old Testament message that God is active in this history for the salvation of his people; that in the Old Testament God's deeds of salvation consistently opens the perspective on the future, on the events of the end time, and bear the promise of eschatological fulfilment ..." (Roberts 1975:14). Paul's emphasis is not on man and his salvation, but rather on God who reveals itself in Scripture and who intervenes in human history to reconcile the world with itself (Roberts 1975:16). "Time and again, in all the letters, salvation is depicted as the work of God" (Roberts 1975:17).

${ }^{13}$ Cf Du Toit (1992). 
Not the christology, nor the pneumatology, but rather the theology - God intervening in history though Christ and the Spirit stands in the centre on behalf of human salvation (Roberts 1975:18). In Paul we do not find any existentialist anthropologising; or any pietistic individualising of salvation; and also no reduction to salvation "facts" (the latter would imply that Cross, Resurrection etc become autonomous "facts" at the centre of theological reflection, which represents a new form of anthropocentrism).

This he motivates by two illustrations (1 Cor 2 and Eph 1-2). In both, the glory of God is presented as the ultimate motivation for the argument presented, referring to the history of salvation (Roberts 1975:19-21). Roberts concludes by suggesting that this theological emphasis dominate the main divisions in the Pauline corpus. These divisions are the God of salvation (Trinitarian perspective), the salvation of God (sin, reconciliation, salvation, liberation, forgiveness, justification and sanctification) and humanity under God's salvation (ecclesiology and ethics).

\section{UNRESOLVED PROBLEMS}

\subsection{Why such ambiguous results?}

From the above discussion it is clear how diverse the different readings of Pauline theology are. Different readings may not be in active conflict with one another and may even be complimentary, but this does not solve the initial problems that gave rise to the search for a centre. Research has not produced an objective criterion by means of which we can judge whether a work is truly Pauline or not; and at present scholars are further than ever from a consensus on a strategy to explain the different aspects of Pauline theology. It seems that the search for a centre has ironically "deconstructed" itself into a myriad of approaches, each with an implied claim that it provides access to the "real" centre of the Pauline text.

\subsection{Why a search for a core?}

The history of the search for a Pauline centre seems to suggest the impossibility of the enterprise. It also suggests that it is time that we take a step back from our interpretative work and pose the question: Why the search for a core? What in our intellectual culture 
had initiated this search in the first place? Either our methodologies are inadequate and in need of one "super" method that will allow us access to the centre of the text in an indisputable scientific manner, or the texts themselves allow for different readings.

Is it not time that we abandon the essentialism (or logocentrism) that drives this outreach for the essences of things? Perhaps texts, or grous of texts, do not have "centres". This does not mean that the views discussed above should be rejected as irresponsible efforts. However much they differ, they are all forthcoming from serious and able scholars. For assessing the search for a centre we now turn to text theory. In this regard we shall note the important work of Daniel Patte (1990) on multi-dimensional exegesis.

\section{GREIMAS/PATTE: MULTI-DIMENSIONAL EXEGESIS}

\subsection{Multi-dimensional exegesis}

In a recent study, Patte is interested in the phenomenon that different scholars arrive at different readings of the Sermon on the Mount. ${ }^{14}$ Through a highly technical analysis of four types of readings, he arrives at two important conclusions:

- Different readings are the result of focusing on different meaning-producing levels in the text; and

- There are important ethical reasons why a scholar chooses to enter the text at one meaning-producing level rather than another.

In his study of different readings of the Sermon on the Mount, he identifies four types of a readings, each supporting a different types of ethic:

- Historical-critical and especially redaction-critical readings arrive at viewing the text as a realistic narrative. This type of reading usually supports a deontological ethic.

\footnotetext{
${ }^{14}$ See Patte (1996b).
} 
- Scholars who use literary criteria see the text as the unfolding of a plot, or a narrative. There is a focus on the transformation of characters and situations, while a plot is defined as a set of events linked by temporal succession and causality. This type of reading usually implies a consequentialist ethic.

- Readings dwelling on the figurative dimension of the text see the text as an exponent of an "intuitive ethical practice," grounded in a vision. A figurative reading is sensitive to the semantic deep structures of a text (Patte 1996a:36) and usually supports a perfectionist ethic.

- In a thematic reading priority is given to the internal semantic organisation of the text, that is to its internal, semantic structure, and the system of convictions which this-structure conveys (Patte 1996a:37). The ethic involved, can either be deontological or perfectionist.

\subsection{Structural semiotics}

In order to explain the differing readings, Patte turns to the structural semiotic theory of Greimas to identify the meaning-producing levels in the text that give rise to the differences. ${ }^{15}$ The basic insight of the model is that meaning is produced by the interaction of syntactic and semantic components in a text. This interaction takes place on several levels, ranging from the fundamental, deep level to the surface or discourse level. In the model below, the four different readings of the Sermon on the Mount, can be described as follows:

- A historical-critical reading corresponds with the syntactic aspect of the text on a semio-narrative level;

\footnotetext{
is In Paul's faith and the power of the gospel Patte (1983) explores the difference between Paul's convictional structure and the ideas by means of which these convictions are extrapolated, while at the same time paving the way for the practice of multiple readings of the same text. In 1996 he published The ethics of biblical interpretation, encouraging biblical interpreters to take responsibility for their interpretation demonstrating that no method of interpretation is value-free. The theoretical basis for this part of the article is developed in The religious dimensions of biblical texts: Greimas' structural semiotics and biblical exegesis (Patte 1990).
} 
- A literary reading corresponds with the syntactic aspect of the text on a discursive level;

- A figurative reading corresponds with the semantic aspect of the text on a discursive level;

- A thematic reading also corresponds with the semantic aspect of the text on a discursive level.

These differing levels can be found in all texts, and can be represented as follows:

\begin{tabular}{|l|l|l|l|}
\hline \multicolumn{4}{|c|}{ GENERATIVE TRAJECTORY - GREIMAS } \\
\hline \multicolumn{2}{|c|}{} & Syntactic Components & Semantic Components \\
\hline $\begin{array}{l}\text { Semio- } \\
\text { narrative }\end{array}$ & Deep Level & Fundamental Syntax & Fundamental Semantics \\
\hline $\begin{array}{l}\text { Structures } \\
\text { Surface } \\
\text { Level }\end{array}$ & Narrative Syntax & Narrative Semantics \\
\hline $\begin{array}{l}\text { Structures } \\
\text { Siscurive }\end{array}$ & $\begin{array}{l}\text { Discursive Syntax } \\
\text { Discursivation: } \\
\text { actorialization } \\
\text { temporalization } \\
\text { spatialization }\end{array}$ & $\begin{array}{l}\text { Discursive Semantics } \\
\text { Thematization } \\
\text { Figurativation }\end{array}$ \\
\hline
\end{tabular}

\subsection{Adjustments to general text theory}

There is, of course, no such thing as a comprehensive and adequate text theory. The reason for this is that we do not fully understand the complexity of language. Nevertheless, the above framework of Greimas proved to be a useful hermeneutical tool to Patte. One shortcoming of the above model is that it deals with the text in a disembodied way by only taking into account text-internal aspects. An aspect of the text that has increasingly received attention during the last years is the material or physical aspect of 
the text. This author suggests that the aspect of medium (representing the material aspect of a text) be included in the generative trajectory of Patte/Greimas.

In refining the model, I have also projected a more gradual transition from deep to surface levels than found in Greimas' theory, and I have adapted some of his technical terms. Further, if the model is to be understood within a general communications theory it is necessary to speak of a message rather than a text.

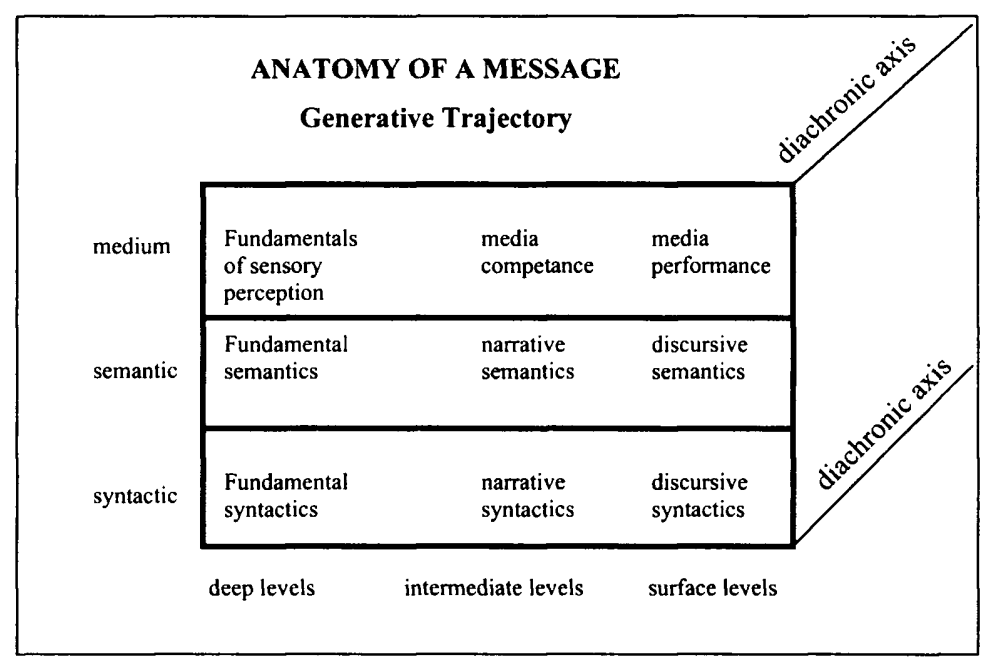

\subsubsection{The media aspect $^{16}$}

On the deepest level of the media trajectory a sender is informed by his/her fundamental construction of reality according to sense perceptions. This field is extensively studied by cognitive linguistics. This basic cognitive competence forms the basis for a more specific media competence. Because of particular cognitive capacities, human beings

${ }^{16}$ The perspectives in this section are extensively argued by Walter Ong (1982). 
develop the capacity to create and manage media. More precisely, the capacity to hear and speak and see is transformed into the ability to access audio-visual signs.

On a higher level of the media trajectory these functions are used to manipulate the material world in order to create physical artefacts that "contain" or "represent" information, for example performing certain gestures, physical sounds or creating marks with ink on papyrus. The technology for these is conditioned by the material culture of society. These "containers" of information may differ according to the available technology; for example, information may be stored in memory, in the form of rituals or taboos, in codices, in libraries, or on hard disk drives, et cetera. These artefacts are being maintained by elaborate systems of power, for example, publishing companies, state institutions.

On the highest level, the media competence enables media performance in specific discourses, which is reflected in the surface of messages and inscribed in texts.

It should also be noted that in the process of interpretation, the material text (whether it is a gesticulated, spoken or written text) provides the only access (=medium) to the meaning of the message. Medium, as indicated in the diagram, is therefore an integral aspect of the trajectory, affecting the other aspects of the trajectory in a dialectical way at all stages of the generative process. The type of syntactical codes used (to generate forms, genres, and canons) and the semantic concepts communicated are codetermined by the possibilities of the medium.

\subsubsection{The semantic aspect}

This aspect of the semantic trajectory relates to the conceptual aspect of messages, though we cannot express semantic contents (=concepts or ideas) without the help of syntactic codes and media functions (as found in the other trajectories). For example, we cannot think of the concept "dog" without delimiting it from other concepts like "cat" et cetera (such delimitation being the result of syntactic codes); and neither can we think of "dog" without some sensory representation, be it either memory of its visual form, or its sound, or a visual memory of the word in its written form (this sensory representation referring to the aspect of medium). 
On the most fundamental semantic level we find the "self-evident" orientation of the sender in terms of "attractions and propulsions" and what is "truly real" and what "seems to be." These "basic ideas" are perceived to be universal, but one of the two may carry more weight. The fundamental semantics is realised in the widest available textual units.

As explained by Patte (1990:84ff) fundamental semantics is converted into narrative semantics by the repeated application of the virtual axiological system (= fundamental pattern). This conversion manifests as a micro semantic universe. The actual semantic universe is only one of many possible ones. On a still higher level, narrative semantics is realised in series of discourses and is responsible for isotopies in a given discourse.

\subsubsection{The syntactic aspect}

On the level of the fundamental syntax the semantic universe is transformed into an expanding "universe of ideas". Through gradual transformations a narrative syntax is established as a relational network that interrelates the transformations. It is only on the discursive level that, for example, stories and arguments finally appear.

\subsection{Using the trajectories to interpret texts}

We have spoken of the three aspects of communication, viz, media, semantics and syntax. This means that every single language unit that can be identified somehow relates to all three aspects, though not on an equal basis. This is one of the mysterious phenomena of language, namely that a message can focus more on one aspect (or level) of the trajectory than another. This could be confusing. To state it in different words; certain aspects (medium, semantics, and syntax) may dominate in certain messages. In a poetic text one would, for example, expect to find that the narrative semantics dominate. In a postmodern text we expect to find an over-determination of the medium aspect (e $\mathrm{g}$, in Joyce's Finnegan's Wake as extreme example).

This "over-determination" of a peculiar aspect is a secondary phenomenon, which does not exclude the integral dependency on the other aspects. The reason for this "over- 
determination" is usually complex. It may better serve the purpose of the sender to focus on one or other aspect, for example, to inscribe it in the surface structure. On the other hand, the inscribing of any aspect of the trajectory in the surface text betrays a high degree of self-conscious behaviour.

Thus far we have mentioned the over-determination of aspects in texts according to their purpose. But what may also happen is that different interpreters may read the text according to different aspectual modes. This will result in different readings, sometimes with results that differ spectacularly. In the case with ancient texts it is difficuit to distinguish whether the aspect/level of the message that is focused has been so intended by the sender or understood so by the interpreter. Nevertheless, it is a theory that explains why we get different readings. It also assists us in relating the different readings to one another, though we must candidly admit that harmonising is not possible and that all attempts at harmonising, would - at this stage of research at least - amount to a forced interpretation.

\subsection{The tri-focal nature of interpretation}

In sum, when dealing with interpretation we have to understand the tri-focal nature of the interpretation process.

- All messages reflect - sometimes in obscure ways - all the aspects of the generative trajectory.

- The specific message under investigation employs the aspects of the generative trajectory in specific ways, that is by the over-determining of certain meaningproduction strategies and the suppression of others.

- The interpreter, because of his/her own generative strategies, tends to target some meaning-producing strategies while suppressing, or overlooking, some others. ${ }^{17}$

\footnotetext{
17 "Readings focused upon the history/realistic narrative dimension of the text necessarily and ignore other of its meaning-dimensions in the same way that, in the well known cognitive test, the perception of the vase (or candlestick) focuses our attention upon features of the drawing which hides from us the two face (persons) looking at each other which are represented by the same image" (Patte 1996a:30).
} 
In an ideal reading a reader would be equally aware of all three the above aspects though this may never be humanly possible.

The advantages of the above text theory are obvious. It does not pretend to understand language completely, or that it can relate all the aspects of language/texts to one another. It rather provides a broad framework that preserves the mystery of language and prevents interpreters from an imperialistic domination of the text. This is a most necessary corrective because of our natural tendencies to absolutise a particular point of view. $^{18}$

The model also reminds us that any intensive study of one meaning-producing level of a message inevitably leads to the other levels. If a comprehensive text theory were available, we could have been able to relate the different aspects of the text to one another. However, due to the lack of such a theory we tend to be at a loss how to move from one level to another. Nonetheless, we are bound to make such transitions because texts function holistically and interpreters who enter the text at different levels eventually are eventually forced to account for other levels as well.

\section{TYPOLOGY OF MODELS FOR PAULINE THEOLOGY}

Pauline studies have fallen into disrepute in many quarters. Some see Paul as a quarrelsome, arrogant, patriarch and misogynist. ${ }^{19}$ Also as a self-contradictory, haphazard thinker, responsible for much confusion in the church. ${ }^{20}$ Pauline theology as such, has also lost much of its vigour. It seems as if there is little more to add to the confusion that already exits. From the final discussions of the Pauline Theology Group at the Annual Meeting of the SBL in 1995 it became obvious how much the search for the "core" of Pauline theology was still alive, despite all the impasses that it encountered during the preceding years that the Group was investigating this. Somehow they did not advance further that Beker's contingency-coherence model.

\footnotetext{
18 It is the apparent inevitable tendency of interpeters to form "Gestalts" - that is, the tendency to generalise their methodology into comprehensive, holistic, strategies that presuppose universal values (even when they protest the relativity of their own methods).

${ }^{19}$ Cf Elliott (1994:3-24) for a review of negative Pauline images.

${ }^{20}$ Cf Räsänen (1986).
} 
From a critical point of view it seems obvious that the lack of progress in this field has to be ascribed to the absence of an adequate text theory.

\subsection{Application to Pauline research}

Once we understand the generative trajectories of a message, it becomes a question of routine to identify the various leves of meaning that were examined in the search for a core. Moreover, the shortcomings of past efforts come into focus. In this regard, we shall return to the work by Roberts and Beker. But let us first investigate the different meaning-producing levels that were focused on in the past. Each of these provides coherence to the text(s) on a specific level. As already mentioned all the levels are present in message production, though the sender or receiver may subconsciously suppress some. (The following list inevitably involves a simplification.)

- Fundamental semantics and syntax. Little attention had been paid to this level of coherence, since the Pauline texts share its fundamental convictions with the rest of the New Testament.

- Narrative syntax. Historical-critical studies mostly focus on this level. The level of the text that is focused upon is that of the realistic historical narrative, as it unfolded over a period of time (on the diachronic axis).

- Narrative semantics. On this level attention is being paid to the basic symbolic structures present in the message.

- Discursive syntax. Various approaches to Pauline theology entered at this level. The focus is then on the text as the unfolding of plot and character. The narratives underlying the text can be seen as the coherence. Another type of study focusing on this level is exemplified by that of Hübner $(1990,1993)$, who sees the recontextualisation of the Old Testament in the New as basic to the theology it expresses.

- Discursive semantics. Traditional approaches to the Pauline materials seldom went further than a thematic analysis of the text. More recent structural analyses of Pauline texts also focus on this level (e g, Beker; Patte).

- Media competence and performance. This aspect has been neglected in Pauline studies, and has only recently begun to draw attention, for example, by socio- 
rhetorical criticism. In previous articles, this author has demonstrated that the Pauline media competence provided an important coherence to text and can be a useful hermeneutic tool. ${ }^{21}$

These different approaches are often chosen in correspondence with particular ethical agendae. Thus we find that:

- Scholars who concentrate on themes usually find such themes to be important to their own ethical agenda (in a deontological sense, focusing on love, the church, women's issues, etc.);

- Those concentrating on structural studies find the process of transformation from deep to surface values to be a model for how theology should be done (contemporary applications);

- Historical analysts usually have some apologetic agenda - either affirming the reliability of the faith or redressing some misunderstandings (concerning themselves with the question of truth, reliability and authority);

- Narrative analysts focus on the dynamic qualities of the text (implying a gentle, open-ended, usually liberal, ethic).

\subsection{The relationship between critical assumptions and ethical conclusions}

It is almost a cliché that no investigation, not even those with the most neutral and objective appearances, is neutral. The more difficult undertaking is to show the relationship between critical assumptions and the conclusions for teaching. There is a vital interaction between our critical assumptions of a text and the ethical conclusions that we draw from the text. Let us now look at the correlation between the critical assumptions of some approaches, and their ethical positions.

- Liberal approach (e g, Weiss). This approach, popular in the 19th century, perceived personal, individual responsibility as strategy in text and equated spirit of Christ with ethical correctness. The ethical implications drawn from this

\footnotetext{
21 "Orality and Pauline 'Christology': Some hermeneutical implications" (Loubser 1993) and "Orality and literacy in the Pauline corpus" (Loubser 1995).
} 
critical assumptions was to reinforce a vested interest in the practice of value-free science, tacitly allowing for global dominance by staging itself as universal model.

- Consistent eschatology (e g, Schweitzer). The critical assumption of this approach concerned the distinction between the imminent/delayed parousia (theme), thus providing an explanation for the mysticism in the text. The ethical complement to this approach was an existentialist, experiential interpretation of Christianity, dwelling on historical relativity and inspiring cultural humility and general Christian humanism.

- Dialectical eschatology (e g, Bultmann). The critical assumption involved the two ages scheme and led to the demythologisation of eschatology and the reinterpretation of salvation by faith in terms of anthropology. The ethics of this approach was that of dialectical existentialism (Bultmann's emphasis on decision) and of a type of self-understanding consonant with the Lutheran faith.

- Freedom (e g, Schurmann/Käsemann). The thematic elaboration of justification by faith in terms of cosmic freedom opened the way for a sociopolitical interpretation.

- Charismatic and mystical experiences (e g, Seyoon Kim). The critical assumption that these (real) experiences are pivotal to the Pauline thinking leads to an ethic of personal and religious fulfilment (in the sense of a perfectionist ethic).

\section{CONCLUSION}

\subsection{J H Roberts}

We can now gain a clearer perspective on the model of Roberts. A first observation is the implication that there can only be one "centre" for Pauline theology. This means that Roberts only acknowledges one level of meaning-production as a valid point of entry into the text, thus disempowering all others.

Another observation is that he enters the text on the level of narrative semantics, one level deeper than that of discursive semantics. In fact, he expresses himself strongly against those who have explored the centre of Pauline theology in terms of a thematic 
core, that is, on the level of discursive semantics. In the search for the core, he carefully avoids the historical-critical approach (thus bypassing the narrative syntax and discursive syntax). On a narrative semantic level, he perceives what he calls, a "centre from which Paul thinks, deals with problems and provides the answers." From this "centre" specific themes are then generated as apply to specific situations. It is remarkable that Roberts, in 1974 , already sensed something of a generative approach by pointing to a centre from which specific themes are generated. He is aware of how arbitrary and subjective the choice of a centre is when he says that a centre should not be "too wide" or "too narrow." It is however, in describing this "centre," that we can observe an interesting problem.

According to him the centre consists of a pattern or view of salvation history in which God is the centre and especially God's action through Christ and the Holy Spirit. The distinction between salvation history as centre, and specific themes, appears uncertain, because salvation history itself, as well as God, Christ or the Spirit can also be conceived as themes.

A further question that presents itself is why this focus on salvation history as centre? Some answers may be ventured: (a) It avoided entering into higher criticism of the text, something against which a strong ecclesiastical prohibition existed and would certainly have involved conflict with church authorities. (b) It confirmed a Reformed view of Scripture. (c) It corresponded with a historical self-consciousness of a certain section of the community; reinforcing a sense of mission and purpose, as well as group solidarity.

The notes features are corroborated by the explicit ethical interest of the scholar; a concern for the church (the church is accepted as a given, while humanistic notions are unacceptable - reflecting the interests of the interpretative community; Roberts 1975:2). There is also an apologetic tendency, dealing with the question whether Paul was a falsifier of Christianity or represented an extremist point of view within Christianity (Roberts 1975:3). Regarding the ecumenical discussion between Rome and Reformation, Roberts concludes: "As long as Scripture is differently evaluated in its essence, the chance of advance in the mutual conversation is meagre and only attainable by bypassing the question of truth" (Roberts 1975:5). Here the assumption is that there can only be one true centre. Other tacit interests are: the desire for certainty regarding the 
fact that Paul approaches the diverse questions from a unitary principle; the need for a coherent understanding and description by means of which Paul's theology can by examined in a systematic way (Roberts 1975:3).

\subsection{J C Beker}

Beker was the first scholar to consciously apply transformational-generative principles to the study of Pauline theology, though his lack of a general text theory led to the same shortcomings as that of Roberts. In the light of the text theory developed above, we can much better understand the problem with his model of the coherence. As mentioned earlier, a basic problem that remained unsolved was the accusation that (despite his strong rejection of a mechanistic, fixed core) the very depiction of the coherence as "apocalyptic" gave a fixed content to it. His concession to his critics that his descriptions of the four motifs of the apocalyptic coherence as "themes" were misleading, he never managed to avoid the impression that the four motifs functioned as themes.

His main problem was that he did not exhibit insight into the arbitrary nature of his formulation of coherence. In the many reformulations of his basic position he practically deconstructed his own position (calling it a field of meaning, an apocalyptic substratum and master symbolism, apocalyptic symbolic universe, an indispensable filter, context and grammar and a network of symbolic relations). From this it is clear that there is not only one type of deep structure at stake, but many. This confusion regarding the status and nature of coherence is also illustrated by his confusion of coherence with the concept proprium.

His initial observations focused on the narrative semantic structure by means of which motifs such as imminence, dualism, vindication, et cetera, determined the transformations that occurred on the level of discursive semantics. If we ignore the question whether the term "apocalyptic" was appropriate, it is possible to observe the same phenomena as Beker did in the intermediate levels of the text. These "motifs", however, do not appear as a unit, but rather on different levels. So, for example dualism can also operate as a syntactic code. Whether the presence of this coherence in all Pauline texts is a proof that there were no fundamental shifts in "Paul's" thinking, is 
another question. He admitted that he could not, according to his method, provide any clear solution to the question of the Pauline authorship of Colossians. ${ }^{22}$

Beker criticised rhetorical and sociological approaches to Pauline theology on the grounds that they neglected the coherence. According to him these methods serve to depict Paul as an opportunist, who changes his message to suit the situation (Beker 1988:365). Here we have a pointer to possible ethical interests. He comes out in defence of "Paul" as a consistent theologian. Another ethical pointer we find in his popular treatise on Pauline theology, The coming triumph of God (Beker 1982). In this book, he engages the cosmic aspect of apocalypticism to make progressive statements on sociopolitical issues like racism and the environment. The underlying assumption is that the apocalyptic coherence of Pauline theology inspired a corcern for the whole of the cosmos (a well-known Reformed topos). In spite of this interesting development, Beker's explanation that the contingent Pauline messages were generated from the apocalyptic coherence, in a similar way that Third World theologians operate, appears to be (meae notitiae) wishful thinking. His idea of coherence remains too undefined to allow for a viable comparison. What he probably had in mind, was the process through which messages are generated in an oral tradition.

\subsection{Toward a richer understanding}

This article has shown that competent exegetes cannot solve the mystery of the missing core with finer detective work. In the light of the text theory developed in this article, it should be apparent that it was a dubious enterprise from the onset. It was not only the result of an inadequate text theory, but also the result of a monolithic concept of truth that encouraged theological intolerance in society at large. This concept of truth inspired a deontological ethic and probably functioned within imperialist and chauvinist discourses, endorsing sectional interests. So, for example, the "core" of justification by faith alone, served as anti-Catholic discourse. The emphasis on the charismatic Paul is part of an anti-Reformed discourse. In Roberts' work we observed an a-political, church-oriented, interest, operating in the formulation of a centre, which is unmistakably part of a broader

\footnotetext{
22 "Thus the coherence and contingency scheme protects us from assuming all too easily the shifting character of the coherence of Paul's gospel, as if Paul's coherence is nothing but a culturally-conditioned contingent structure" (Beker 1986:601).
} 
South African discourse. In Beker's work the coherence became the avenue to the "salvaging of Paul" as a theologian with a progressive social agenda, though this agenda contradicted by Beker's implicit concept of truth.

The way to proceed is rather to allow for multi-dimensional exegetical practices and to empower readings that show the othemess of the text. When identifying coherences in the text, Pauline scholars should in future take care to understand the level at which they enter the text and to show a capacity for understanding that there could be multiple coherences. Much may be gained by paying special attention to the media aspect of the text, especially to the oral poetics residual in first century manuscript culture. Pre-critical readings of the texts, such as we find in the African Independent Churches and also in the Coptic and Ethiopian Orthodox Churches, might prove significant in understanding the logic and speech conventions that regulate their reading of biblical texts. Such readings employ a "naïve realism". They are "a-historical" and "communal" and often result in a eclectic "gathering of jewels" (proof texts). ${ }^{23}$ In sermons of the Church of the Nazareners (an independent African church in Kwazulu Natal) a hermeneutic is used that is similar to the hermeneutic that underlies much of the biblical text itself. These sermons reflect the distinct features of religious communication in an oral culture, exhibiting a non-linear structure, open-endedness, a-historical time conception, and a communal awareness. ${ }^{24}$ The sermons do not follow the logic of modern "common sense" and are comparable to the finding of Bassler (1989:414) that "Paul was not a systematic theologian." Furnish (1989:246-247) remarks that it was only among the twelfth century scholastics that theology came to be regarded as a comprehensive, systematic presentation of the gospel.

In the light of the present theoretical poverty, such studies provide a means to "decentre" sophisticated readings and to re-engage scholarship in a creative interaction with pre-literate understandings of the text (cf Lindbeck, in Ford 1989:267). Such studies should help us to acknowledge our relative position as interpreters, to understand the

\footnotetext{
${ }^{23} \mathrm{Cf}$ article on the biblical hermeneutic of the Coptic tradition (Loubser 1997).

24 Cf Loubser (1996), Shembe preaching: A study in oral hermeneutics; The oral Christ of Shembe: Believing in Jesus in oral and literate societies (Loubser 1993).
} 
limitations of our points of view and to resist the tendency to universalise our own interpretations.

\section{Works consulted}

Bassler, J M 1989. Paul's theology: Whence and whither? A synthesis (of sorts) of the theology of Philemon, 1 Thessalonians, Philippians, Galatians, and 1 Corinthians. SBL Seminar Papers, 412-423. Atlanta GA: Scholars Press.

Becker, J 1989. Paulus: Apostel der Völker. Tübingen: J C B Mohr.

Beker, J C 1980. Paul the apostle: The triumph of God in life and thought. Philadelphia: Fortress.

- 1982. Paul's apocalyptic Gospe: The coming triumph of God. Philadelphia: Fortress.

- 1986. The method of recasting Pauline theology. The coherence-contingency scheme as interpretive model. SBL Seminar Papers, 596-602. Atlanta: Scholars Press.

- 1988. Paul's theology: Consistent or inconsistent? New Testament Studies 34, 36477.

- 1989. Paul the theologian: Major motifs in Pauline theology. Interpretation 43, 352365.

- 1993. Christologies and antropologies of Paul, Luke-Acts and Marcion, in de Boer, $M$ C (ed), From Jesus to John: Essays on Jesus and New Testament Christology in honour of Marinus de Jonge, 174-182. Sheffield: Sheffield University Press. (JSNT Supple 84.)

Boers, H 1988. The foundations of Paul's thought: A methodological investigation - the problem of the coherent center in Paul's thought. Studia Theologica 42, 55-68.

Dahl, N A 1962. The particularity of the Pauline epistles as a problem in the ancient church, in Neotestamentica et Patristica, 261-267. Leiden.

Dibelius, M 1953. Botschaft und Geschichte: Gesammelte Aufsätze von Martin Dibelius,

Vol 1: Zur Evangelienforschung. Tübingen: Mohr.

- 1956. Die Formgeschichte des Evangeliums. 3.Auflage. Tübingen: Mohr.

Dodd, C H 1934. The mind of Paul: Change and development. Bulletin of the John Rylands Library 18, 3-44. (Also in NTS 1953, 83-128).

Dunn, J D G 1998. The theology of Paul the apostle. Grand Rapids: Eerdmans. 
Du Toit, A B et al (eds) 1992-1998. Guide to the New Testament, vols 1-6. Pretoria: NG Kerkboekhandel.

Elliot, N 1994. Liberating Paul: The justice of God and the politics of the apostle. Maryknoll, New York: Orbis Books.

Fitzmeyer, J A 1967. Pauline theology: A brief sketch. Englewood Cliffs, NJ: Prentice Hall.

Ford, D F (ed) 1989. The modern theologians: An introduction to Christian theology in the twentieth century, 2 vols. Oxford: Blackwell.

Furnish, V P 1970. Development in Paul's thought. JAAR 38, 289-303.

- 1989. Theology in 1 Corinthians: Initial Soundings. SBL Seminar Papers, 246-264. Atlanta GA: Scholars Press.

Hays, R B 1980. The faith of Jesus Christ. Chico: Scholars Press. (SBLDS 56.)

- 1988. Crucified with Christ: A synthesis of 1. and 2 Thessalonians, Philemon, Philippians and Galatians. SBL Seminar Papers. Atlanta: Scholars Press.

Hübner, H 1987. Methodologie und Theologie: Zu neuen methodischen Ansätzen in der Paulusforschung. KuD 33, 150-75.

- 1990. Biblische Theologic des Neuen Testaments, Band I: Prolegomena. Göttingen: Vandenhoeck \& Ruprecht.

- 1993. Biblische Theologie des Neuen Testaments, Band 11, Die Theologie des Paulus. Göttingen: Vandenhoeck \& Ruprecht.

Kim, S 1981. The origin of Paul's gospel. Tübingen: JCB Mobr (Siebeck). (WUNT 2.)

Longenecker, R N 1964. Paul: Apostle of liberty. New York: Harper \& Row.

- 1985. The nature of Paul's early eschatology. NTS 31(1), 85-95.

Loubser, J A 1993. Orality and Pauline "Christology": Some hermeneutical implications. Scriptura 47, 25-51.

- 1993. The oral Christ of Shembe: Believing in Jesus in oral and literate societies. Scriptura S 12, 70-80.

- 1995. Orality and literacy in the Pauline corpus. Neotestamentica 29(2).

Loubser, J A 1996. Shembe preaching: A study in oral hermeneuties, in Kitshoff, M C (ed), Kaleidoscope of Afro-Christian religion in the African independent churches today. Lewiston: Edwin Mellen Press. 
Loubser, J A 1997. Gathering Jewels-Biblical hermeneuties in the Coptic Orthodox Church. Journal for the Study of religion in Southern Africa 10(1), 41-71.

Lowe, John 1941. An examination of attempts to detect developments in St. Paul's theology. Journal of Theological Studies 42, 129-42.

Moule, C F D 1941. An examination of attempts to detect developments in St. Paul's theology. JTS XLII, $129 \mathrm{ff}$.

- 1959. The influences of circumstances on the use of Christological terms. JTS X, $247 \mathrm{ff}$.

- 1964. The influence of circumstances on the use of eschatological terms. JTS XV,115.

Ong, W J·1982. Orality and literacy; The technologizing of the word. London: Methuen. Ortkemper, F J 1968. Wir verkündigen Christus als den Gekreuzigten (1 Kor 1, 23): Die Kreuzesbotschaft des Apostels Paulus als Mitte seines Evangeliums. Bibel und Kirche 23, 5-12.

Patte, D \& Patte, A 1978. Structural Exegesis: From theory to practice. Exegesis of Mark 15 and 16. Hermeneutical implications. Philadelphia: Fortress Press.

Patte, D 1983. Paul's faith and the power of the gospel: A structural introduction to the Pauline letters. Philadelphia: Fortress Press.

- 1990. The religious dimensions of biblical texts: Greimas's structural semiotics and Biblical exegesis. Atlanta: Scholars Press.

- 1996a. Ethics of biblical interpretation: A re-evaluation. Louisville, KT: Westminster.

- 1996b. Seminar on The Sermon on the Mount at Vanderbilt University, Department of Religious Studies.

Plevnik, J 1989. The center of Pauline theology. CBQ 51(3), 461-78.

Räsänen, H 1986. Paul and the Law. Philadelphia: Fortress.

Ridderbos, H 1971. Paulus: Ontwerp van zijn theologie. Kampen: Kok.

Roberts, J H 1975. Die teologiese sentrum van die Corpus Paulinum. Inaugural lecture at the University of South Africa, presented on 29 August 1974 (reprint). Theologia Evangelica $8(1)$. 
Sanders, E P 1977. Paul and Palestinian Judaism: A comparison of patterns of religion. Philadelphia: Fortress.

- 1983. Paul, the Law and the Jewish People. Fortress: Philadelphia.

Schnackenburg, R s a. Christologic des Neuen Testamentis. Mysterium Salutis 3(1), $227-$ 338.

Stuhlmacher, P 1992. Biblische Theologie des Neuen Testaments, Band 1: Grundlegung van Jesus zu Paulus. Göttingen: Vandenhoeck \& Ruprecht.

Wright, N T 1991. The climax of the covenant. Minneapolis: Fortress. 